\title{
Differential tolerance of eucalyptus clones to sulfentrazone applied in different soil textures
}

\author{
Tolerância diferencial de clones de eucalipto ao \\ sulfentrazone aplicado em solos com diferentes texturas
}

\author{
Caio Antonio Carbonari ${ }^{1}$, Leonardo Guelli Miranda ${ }^{2}$, \\ Giovanna Larissa Gimenes Cotrick Gomes ${ }^{3}$, Gilmar José Picoli Junior ${ }^{3}$, \\ Ana Karollyna Alves de Matos ${ }^{3}$ e Edivaldo Domingues Velini ${ }^{4}$
}

\begin{abstract}
Resumo
O objetivo deste trabalho foi avaliar a intoxicação e os teores de clorofila em dois clones de eucalipto submetidos a aplicação sulfentrazone, em diferentes doses e em solos com diferentes texturas. Foram realizados experimentos com dois tipos de solos de diferentes texturas (arenoso e argiloso). Os tratamentos foram dispostos em esquema fatorial 2 (clones) $\times 4$ (doses de sulfentrazone) e o delineamento experimental utilizado foi inteiramente casualizado com quatro repetições. Foram utilizados dois clones de eucalipto, Eucalyptus urophylla (472) e Eucalyptus urograndis (132) e foram testadas as doses de 200, 400 e 600 $\mathrm{g}$ de sulfentrazone ha-1 e uma testemunha sem aplicação de herbicida. A aplicação das diferentes doses do herbicida foi realizada sobre o solo e em seguida as mudas foram transplantadas para os vasos. As avaliações de intoxicação ocorreram aos 15, 35, 62 e 90 dias após a aplicação das diferentes doses do sulfentrazone e as coletas de folha para determinação dos níveis de clorofila e solo foram realizadas aos 15, 45 e 90 dias após a aplicação do herbicida. Aos 90 dias após a aplicação, as plantas foram coletadas, e suas respectivas massas secas foram determinadas. Os dois clones de eucalipto apresentaram maiores níveis de intoxicação no solo arenoso e o clone de $E$. urophylla mostrou-se mais sensível em relação a aplicação do herbicida sulfentrazone. Os níveis de intoxicação observados para os dois clones foi proporcional à dose de sulfentrazone em ambos os solos e a disponibilidade de sulfentrazone foi muito superior no solo arenoso em relação ao argiloso. As maiores doses de sulfentrazone em ambos os solos promoveram reduções nos níveis de clorofila.
\end{abstract}

Palavras-chave: seletividade, fitotoxicidade, herbicida, pré-emergência.

\begin{abstract}
This study aimed to evaluate the visual injury and concentrations of chlorophyll in two eucalyptus clones submitted to sulfentrazone application, at different doses and in soils with different textures. Experiments were performed utilizing two soil textures (sandy and clayey). The treatments were arranged in a factorial scheme of two (clones) $x$ four (sulfentrazone doses), in a completely randomized experimental design with four replications. Two eucalyptus clones were utilized: Eucalyptus urophylla (472) and Eucalyptus urograndis (132), and were tested at doses of 200,400 and $600 \mathrm{~g}$ of sulfentrazone ha-1 and one control without herbicide application. The different herbicide doses were applied onto the soil, and then the plants were transplanted to pots. Visual injury evaluations occurred at 15, 35, 62 and 90 days after application of the different sulfentrazone doses whereas leaves and soil were collected on days 15, 45 and 90 after herbicide application to determine the chlorophyll levels. At 90 days after application, the plants were harvested and their respective dry masses determined. Both eucalyptus clones presented higher intoxication levels in sandy soil while the $E$. urophylla clone proved more sensitive in relation to sulfentrazone application. The visual injury levels observed in the two clones was proportional to the sulfentrazone dose in both soils, while sulfentrazone availability was much greater in sandy than clayey soil. The highest sulfentrazone doses in both soils promoted diminished levels of chlorophyll.
\end{abstract}

Keywords: selectivity, phytotoxicity, herbicide, pre-emergence.

\footnotetext{
${ }^{1}$ Assistant Professor, Phd. UNESP - Universidade Estadual Paulista "Júlio de Mesquita Filho" / FCA - Faculdade de Ciências Agronômicas - Departamento de Produção e Melhoramento Vegetal. - 18610-307 - Botucatu/SP, Brazil. E-mail: carbonari@fca.unesp.br.

${ }^{2}$ Undergraduate student. UNESP - Universidade Estadual Paulista "Júlio de Mesquita Filho" / FCA - Faculdade de Ciências Agronômicas - Departamento de Produção e Melhoramento Vegetal. - 18610-307 - Botucatu/SP, Brazil.

${ }^{3}$ Graduate students. UNESP - Universidade Estadual Paulista "Júlio de Mesquita Filho" / FCA - Faculdade de Ciências Agronômicas - Departamento de Produção e Melhoramento Vegetal. - 18610-307 - Botucatu/SP, Brazil.

${ }^{4}$ Full Professor, Phd. UNESP - Universidade Estadual Paulista "Júlio de Mesquita Filho" / FCA - Faculdade de Ciências Agronômicas - Departamento de Produção e Melhoramento Vegetal. - 18610-307 - Botucatu/SP, Brazil.
} 


\section{INTRODUCTION}

The cultivation of eucalyptus has acquired great national importance since it generates raw material for the production of cellulose and paper, charcoal, furniture and energy. In 2012, the eucalyptus cultivation area totaled 5.1 million hectares, representing growth of $4.5 \%(228,078$ ha) in relation to the previous year (ABRAF, 2013). According to ABRAF (2013), 53\% of the areas with planted eucalyptus forests in Brazil are located in the southeast, most prominently the state of Minas Gerais $(1,491,681 \mathrm{ha})$ followed by São Paulo $(1,186,497 \mathrm{ha})$, accounting for $22.4 \%$ and $17.8 \%$, respectively, of the whole country. In addition to its important role in the Brazilian economy, eucalyptus cultivation is promising as a source of renewable energy and its contribution to the sequestration of $\mathrm{CO}_{2}$ from the atmosphere (Olivette et al., 2011).

Weed management in eucalyptus cultivations has assumed a leading role among farming practices, presenting a direct effect on yield and production costs (Machado et al., 2010), being one of the most expensive activities, and a highly important component from the initial phase of the cycle until the forest is established (Toledo et al., 2003). The use of herbicides in the forest and agricultural sectors is crucial since the productivity losses provoked by weed interference are very significant and due to the extension of areas planted with eucalyptus.

According to Carbonari et al. (2010), herbicides that present post-emergence action against weeds, especially glyphosate, are still widely utilized in the control of weeds in eucalyptus, since it presents high efficacy in their control. Nevertheless, these herbicides, principally glyphosate, provide only momentary control due to an absence of a residual effect in the soil while it can even cause severe damage to the eucalyptus on account of a lack of selectivity (Tuffi-Santos et al., 2006; Tuffi-Santos et al., 2007). Thus, some advantages have been demonstrated from applying selective herbicides against weeds in pre-emergence and with an extensive period of residual effect in the soil, especially through reducing the number of weed-control operations.

Sulfentrazone is prominent among the few options of herbicides that act prior to weed emergence registered in Brazil for eucalyptus. Sulfentrazone is a member of the aryl triazolinones chemical group, which controls mono- and dicotyledonous weeds in eucalyptus crops. This herbicide is recommended for eucalyptus at doses of 400 to $800 \mathrm{~g}^{\text {a.i. }}$ ha $^{-1}$ (Rodrigues and Almeida, 2011). According to these authors, sulfentrazone presents a water solubility of $490 \mathrm{mg} \mathrm{L}^{-1}$ and vapor pressure of $1 \times 10^{-9} \mathrm{~mm} \mathrm{Hg}$ at $25^{\circ} \mathrm{C}$. In soil, its mobility is moderate, with low adsorption and unknown Koc, pKa of 6.6, with microbial decomposition constituting the principal route of degradation, and a half-life of 180 days (FMC, 1997).

Sulfentrazone belongs to the group of PROTOX-inhibitor herbicides (protoporphyrinogen oxidase). After this enzyme is inhibited, protoporphyrin IX is accumulated, permitting the formation of singlet oxygen, which is responsible for the peroxidation of the plasmatic membrane and of the tonoplast (Scalla et al., 1990). In addition to the protoporphyrin IX accumulation and singlet oxygen production, the chlorophyll production is inhibited by a blockage of the route (Duke et al., 1991). Sulfentrazone is absorbed by plants by means of the root and leaves, but the movement of herbicide in the phloem is limited due to the rapid compromise of leaf tissues (Rodrigues and Almeida, 2011).

Despite the fact that sulfentrazone is a herbicide recommended for eucalyptus cultivation and presents very interesting characteristics in relation to the control spectrum and period of weed control (long residual period), this herbicide frequently presents problems of eucalyptus injury, especially in the first month after planting of the seedlings. According to field observations, this injury caused by sulfentrazone often is related to dose adjustment related to the soil texture and/or eucalyptus clone, however, there is no scientific information to report and prove this fact.

According to Dayan et al. (1996) and Dayan et al. (1997), the principal factor for the tolerance of some plants to sulfentrazone appears to be differential metabolism, although other effects such as developmental retardation of root hairs in Cassia ocidentalis L. and differential cellular damage in soy cultivars, may also be important factors. The limited movement of the herbicide from the site of application to the site of action, molecular modifications of the action site and rapid metabolization are also indicated as important characteristics related to tolerance to this herbicide (Vaughn and Duke, 1991). 
The present work aimed to evaluate visual injury and the concentrations of chlorophyll in two eucalyptus clones submitted to sulfentrazone application, at different doses and in soils with different textures.

\section{MATERIAL AND METHODS}

The experiments were conducted in a greenhouse, at the Nucleus for Advanced Research in Weed Science, a part of the College of Agricultural Sciences - UNESP campus in Botucatu, Sao Paulo state, Brazil. The pots utilized had a capacity of 11 liters of soil. Experiments were installed with two soil types, denominated clayey and sandy. The physical and chemical characteristics of the two soils are displayed in Tables 1 and 2. According to the result of the analyses, corrective fertilizer application was performed utilizing urea, triple superphosphate and potassium chloride, and correction with lime to leave the soil in good fertility conditions for eucalyptus cultivation.

Table 1. Results of granulometric analysis of soils utilized in the experiments.

Tabela 1. Resultados da análises granulométricas dos solos utilizados nos experimentos.

\begin{tabular}{lcccc}
\hline \multirow{2}{*}{ SAMPLE } & Sand & Clay & Silt & \multirow{2}{*}{ Texture classification } \\
\cline { 2 - 3 } & & $\mathbf{g ~ k g}^{-1}$ & & Clayey \\
Clayey soil & 343 & 463 & 194 & Sandy \\
Sandy soil & 881 & 99 & 20 & \\
\hline
\end{tabular}

Table 2. Results of chemical analysis of soils utilized in the experiments.

Tabela 2. Resultados das análises químicas dos solos utilizados nos experimentos.

\begin{tabular}{|c|c|c|c|c|c|c|c|c|c|c|c|c|}
\hline \multirow{2}{*}{ SAMPLE } & $\mathrm{pH}$ & M.O. & Presina & $\mathrm{Al}^{3+}$ & $\mathrm{H}+\mathrm{Al}$ & $\mathbf{K}$ & $\mathrm{Ca}$ & $\mathrm{Mg}$ & SB & CTC & V & $\mathrm{S}$ \\
\hline & $\mathrm{CaCl}_{2}$ & $\mathrm{~g} / \mathrm{dm}^{3}$ & $\mathrm{mg} / \mathrm{dm}^{3}$ & \multicolumn{7}{|c|}{$\mathrm{mmolc} / \mathrm{dm}^{3}$} & $\%$ & $\mathrm{mg} / \mathrm{dm}^{3}$ \\
\hline Clayey soil & 4.2 & 10 & 6 & 9 & 54 & 0.2 & 4 & 2 & 6 & 60 & 10 & 28 \\
\hline Sandy soil & 5.1 & 16 & 4 & 0 & 13 & 0.5 & 11 & 5 & 16 & 29 & 54 & 2 \\
\hline
\end{tabular}

The treatments were arranged into a factorial scheme: two (clones) x four (doses of sulfentrazone) and the experimental design utilized was completely randomized with four replications. Two eucalyptus clones were utilized, Eucalyptus urophylla (472) and Eucalyptus urograndis (132), acquired from the forest products company Eucatex and tested at the doses of 200, 400 and $600 \mathrm{~g}$ of sulfentrazone $\mathrm{ha}^{-1}$ and one control without herbicide application. The commercial product utilized for the preparation of spray solutions was Solara $500^{\circledR}$.

Pulverization of the different sulfentrazone doses was carried out in a stationary spraying system equipped with four DG $11002 \mathrm{VP}$ nozzles, spaced $0.5 \mathrm{~m}$ apart, and arranged at a height of $0.5 \mathrm{~m}$ in relation to the pots. The climatic conditions at the moment of application presented variations between 28 and $29^{\circ} \mathrm{C}$ and a relative humidity from 50 to $54 \%$. After application of the treatments in the pots with the two soil types, the seedlings of the different eucalyptus clones were transplanted and submitted to irrigation by surface daily with known quantities of water into all the pots.

Plant injury was visually assessed at 15, 35, 62 and 90 days after application (DAA) by assigning scores between 0 and 100\% ( 0 corresponds to an absence of symptoms and 100\% to plant death) (SBCPD, 1995). At 15, 45 and 90 DAA, soil samples were collected using a auger (especially for pots), with four simple collections in different positions and pot depths for the formation of a composite sample, then being stored in a plastic bag and kept frozen at $-20^{\circ} \mathrm{C}$ until processing, for quantification of sulfentrazone in the soil.

Collections of two leaves (one new and one mature) were made from the plants of the different treatments at 15, 45 and 90 DAA. These leaves were washed with distilled water, stored in plastic bags, frozen in liquid nitrogen and conditioned in a freezer at $-80^{\circ} \mathrm{C}$ to determine levels of chlorophyll. At 90 days after application the aerial part and root system of the eucalyptus plants were collected; conditioned in paper bags and dried in a forced air oven at $60^{\circ} \mathrm{C}$, for seven days. Subsequently, the dry mass was weighed on a precision balance $(0.001 \mathrm{~g})$ to determine the biomass of the aerial part and root system. 


\section{Preparation of samples and analysis of compounds}

The soil samples were dried in a forced air oven at $40^{\circ} \mathrm{C}$ (to avoid degradation of sulfentrazone), for a period of 72 hours, until the material was totally dry. After drying, $10 \mathrm{~g}$ of soil from each sample was placed into plastic cartridges, with a porous small pouch and compartment in which to collect soil solution. The soils samples were saturated with distilled water and the water quantity was determined for each cartridge with soil, by weighing before and after saturation with water. After the addition of water, the cartridges were centrifuged at $3800 \mathrm{~g}$ at $25^{\circ} \mathrm{C}$ for 10 minutes; a fraction of solution present in soil was removed and collected for quantification of sulfentrazone, according to the methodology described by Carbonari (2009).

Sulfentrazone was quantified in an LC-MS/MS system composed of High Performance Liquid Chromatography (HPLC) and a 3200Q TRAP mass spectrometer, hybrid triple quadrupole. For the chromatographic analyses a C18 column was used, Synergi $2.5 \mu$ Hydro-RP $100 \AA$. The analyses were carried out in gradient mode, having as mobile phases the solvents acetic acid (0.5\%) in water (PA) and acetic acid (0.5\%) in methanol (PB). The flow utilized was $0.25 \mathrm{ml}$ minute ${ }^{-1}$ and the proportion between the solvents was initiated at 50:50 (PA:PB), and at 1 minute arrived at 5:95 (PA:PB), then was returned to the initial condition at 7 minutes. The total run time was 10.0 minutes whereas the sulfentrazone retention time was 4.56 minutes. The source ESI (electrospray ionization) was utilized, operating in a positive mode.

The samples of leaves were macerated in a mortar with liquid nitrogen, and an aliquot of $200 \mathrm{mg}$ was weighed and stored in $15 \mathrm{ml}$ centrifuge tubes, into which $10 \mathrm{ml}$ of a solution of $80 \%$ acetone $(\mathrm{v} / \mathrm{v})$ was added. The tubes were maintained at rest in darkness for 30 minutes and subsequently centrifuged at $3800 \mathrm{~g}$ for 10 minutes. The supernatant was collected to determine the content of total chlorophyll (chlorophyll a + chlorophyll b) by spectrophotometry. The wavelengths utilized in the readings were 663 and $647 \mathrm{~nm}$.

Chlorophyll determinations $\left(\mathrm{mg} \mathrm{g}^{-1}\right)$ were based on the equations proposed by Lichenthaler (1987): Chlorophyll a = (11.25 x A663 - 2.79 x A647); Chlorophyll b = (21.5 x A647 - 5.1 x A663); where $\mathrm{A}$ is the absorbance at the wavelength indicated.

\section{Statistical analysis}

The data for dry mass and photosynthetic pigments were submitted to analysis of variance by the $\mathrm{F}$ test and the means were compared by Tukey's test ( $\mathrm{p} \leq 0.05)$. Regression analyses of visual injury for all periods of evaluation were performed. To represent the behavioral tendency of phytotoxicity, the means of the different evaluations were submitted to regression analysis, as were the results on herbicide availability in the soil.

\section{RESULTS AND DISCUSSION}

The plant injury results for eucalyptus clones in sandy soil, at 15 DAA, reveal the first symptoms that continued evolving and that came to be more intense starting at 35 DAA (Figure 1). The highest intoxication levels were observed between 62 and 83 DAA for both clones (Figures 1 and 2). The injury symptoms displayed were proportional to the tested doses. It is noteworthy that the clone of E. urophylla showed lower sensitivity to sulfentrazone than did the E. urograndis clone. This finding is better highlighted in Figure 3 (A), where the intoxication means of the different doses are displayed for the two clones in sandy soil.

As to the clayey soil, the injury levels were generally lower than those found in sandy soil, especially for $E$. urograndis. At 7 DAA the first symptoms of the visual injury were observed and continued to evolve only at the / a higher dose of sulfentrazone until 62 and 83 DAA for E. urophylla (Figure 2). The clone of $E$. urograndis presented highly similar visual injury levels in all the evaluated periods, although they were proportional to the tested doses. Most notably, the E. urophylla was shown to be more sensitive to sulfentrazone than the E. urograndis. Figure 3 (B) displays the sensitivity difference between the two clones to sulfentrazone for the mean of the different doses and evaluation periods. 

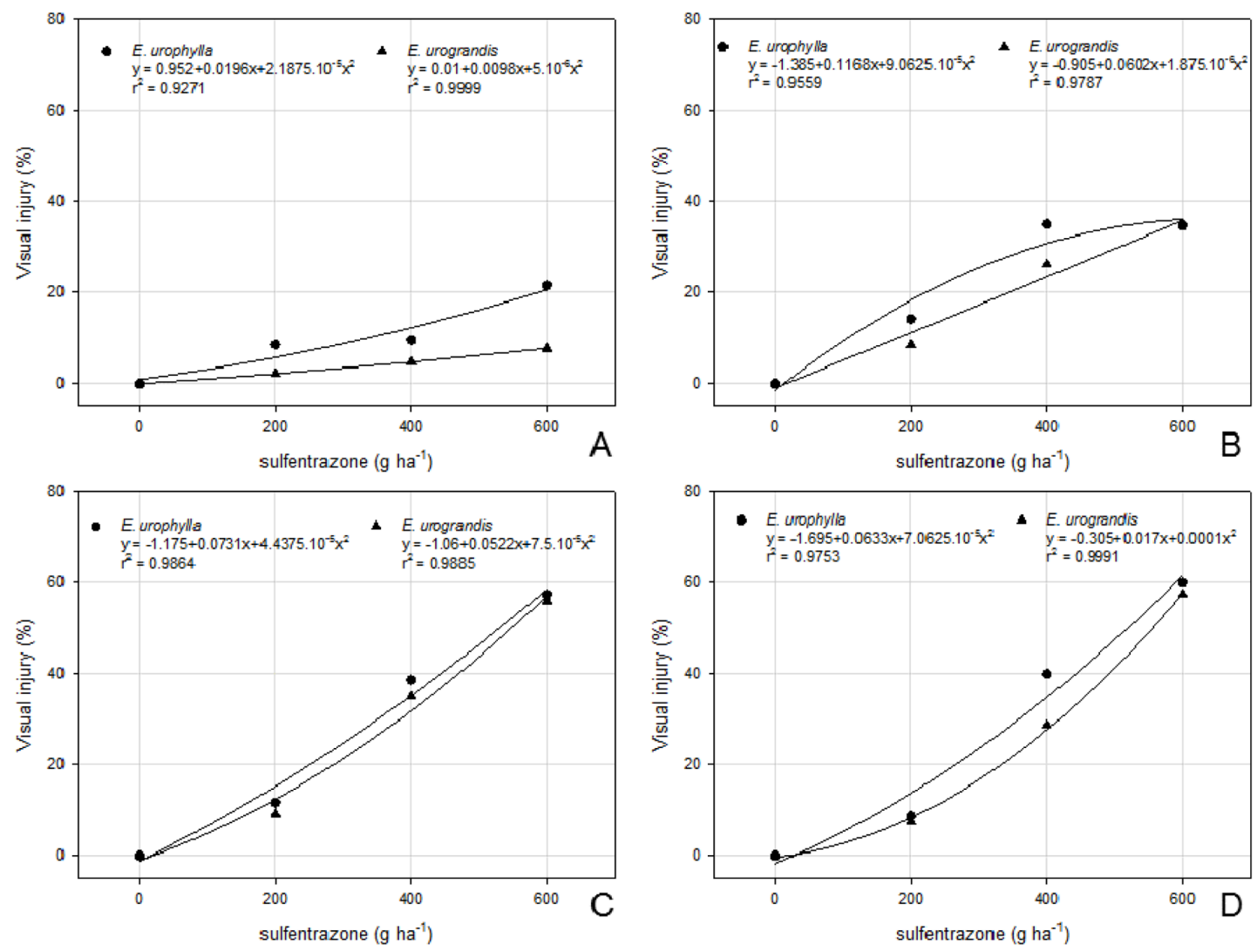

Figure 1. Percentage of visual injury in plants of E. urophylla and E. urograndis 15 (A), 35 (B); 62 (C) and 83 (D) days after the application of different sulfentrazone doses in sandy soil.

Figura 1. Porcentagem de intoxicação em plantas de E. urophylla e E. urograndis aos 15 (A), 35 (B); 62 (C) e 83 (D) dias após a aplicação de diferentes doses de sulfentrazone em solo arenoso.
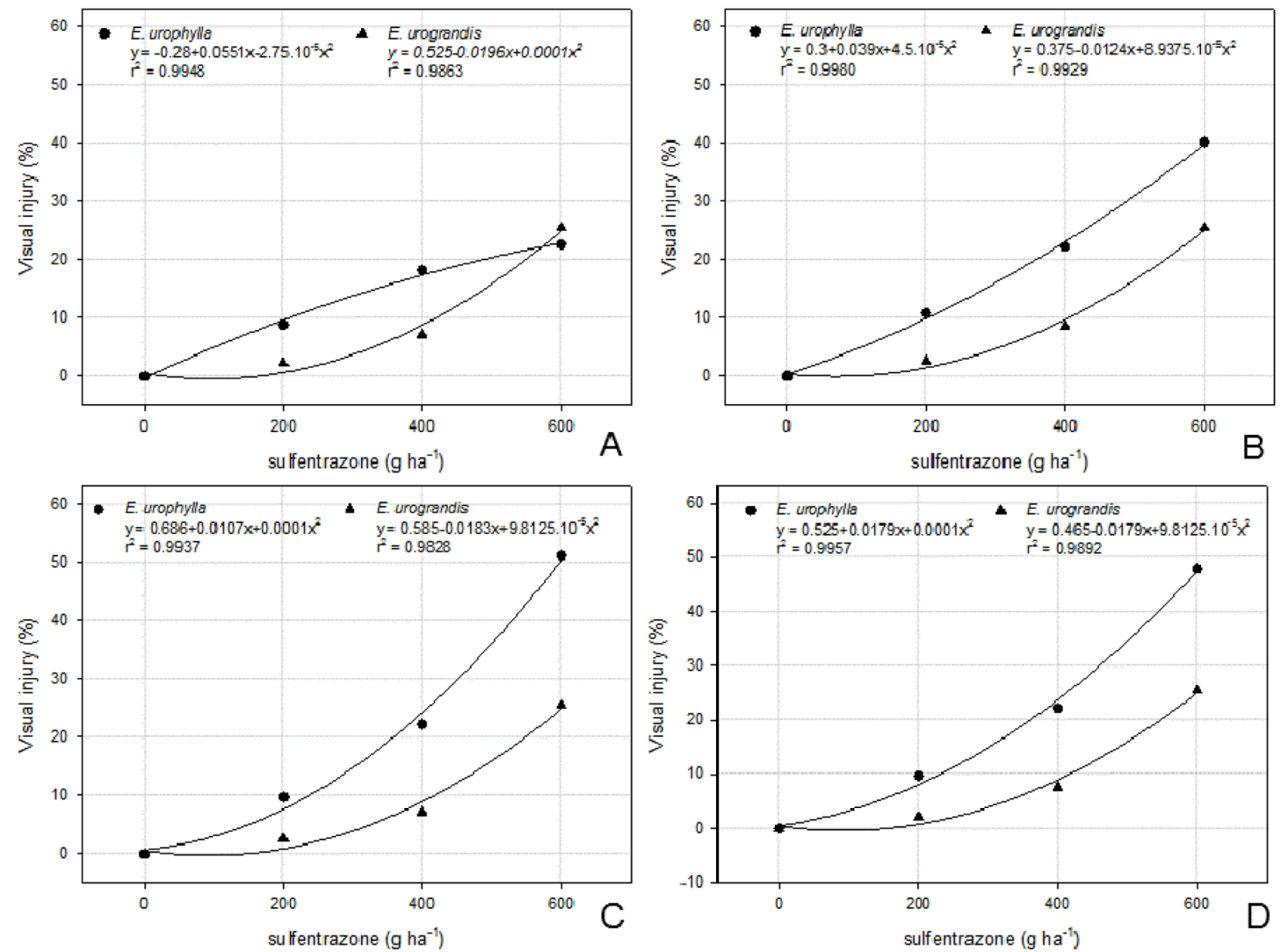

Figure 2. Percentage of visual injury in plants of $E$. urophylla and $E$. urograndis (A), 35 (B); 62 (C) and 83 (D) days after the application of different sulfentrazone doses in clayey soil.

Figura 2. Porcentagem de intoxicação em plantas de $E$. urophylla e $E$. urograndis aos 15 (A), 35 (B); 62 (C) e 83 (D) dias após a aplicação de diferentes doses de sulfentrazone em solo argiloso. 

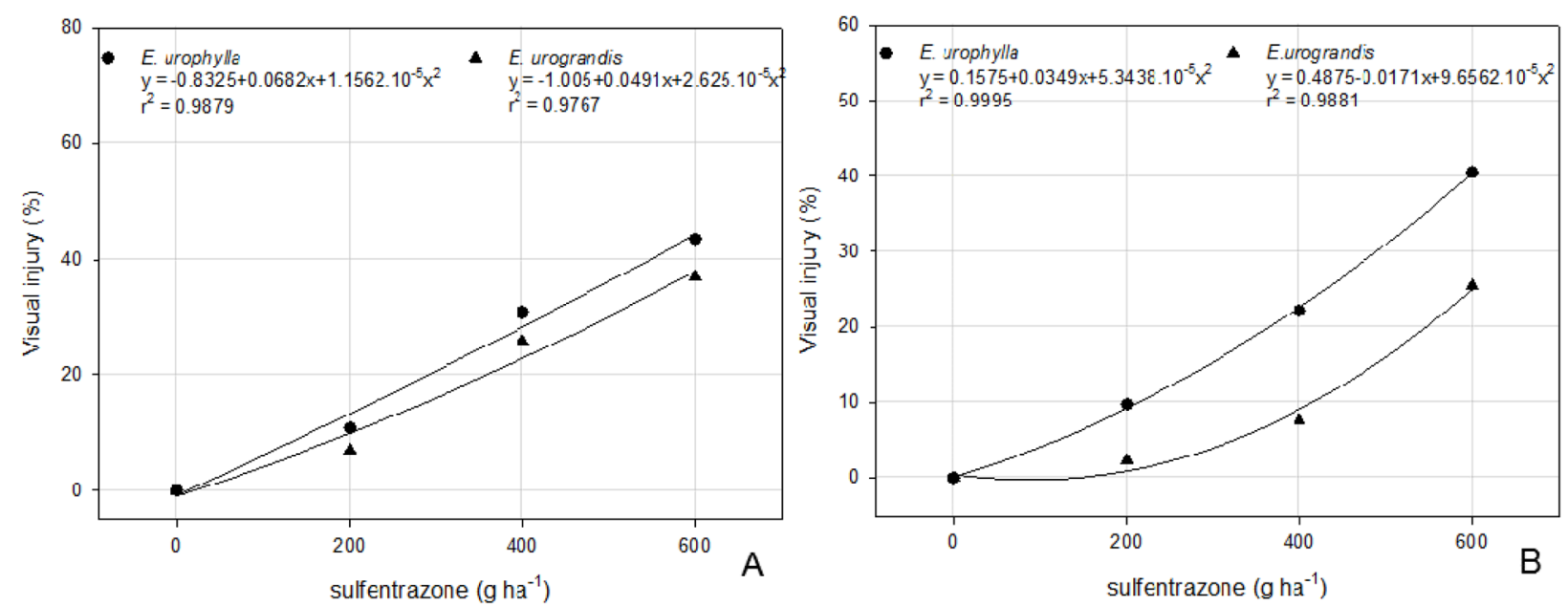

Figure 3. Mean intoxication percentages of eucalyptus plants submitted to sulfentrazone application at different doses in sandy $(A)$ and clayey soil (B).

Figura 3. Porcentagem média de intoxicação de plantas de eucalipto submetidas à aplicação de sulfentrazone em diferentes doses em solo arenoso (A) e argiloso (B).

The symptoms observed in the plants ranged from purplish coloration of the secondary veins to in some cases of the entire foliar tissue. Carbonari et al. (2012), evaluating the phytotoxicity of two sulfentrazone doses in two eucalyptus clones, observed significant selectivity differences between the two clones, with the higher sulfentrazone dose posing the most critical condition for both clones. The same authors found that difference in sensitivity between the two studied clones was related to differential absorption of sulfentrazone from the soil by eucalyptus roots.

With regard to the dry mass of the aerial part of the plants in sandy soil, only the higher dose promoted a significant diminution of biomass in both clones while there was no significant difference between the clones tested (Table 3 ). As to the dry mass of the root, in sandy soil, again the higher dose promoted significant biomass reductions whereas the E. urograndis presented greater accumulations of biomass independent of the treatment (Table 3).

Table 3. Dry mass of aerial part and roots of eucalyptus plants submitted to application of different sulfentrazone doses in sandy soil.

Tabela 3. Massa seca da parte aérea e raízes de plantas de eucalipto submetidas à aplicação de diferentes doses sulfentrazone em solo arenoso.

\begin{tabular}{ccc}
\hline \multirow{2}{*}{ Doses of sulfentrazone $\left.\mathbf{( g ~ h a}^{-1}\right)$} & \multicolumn{2}{c}{ Clone } \\
\cline { 2 - 3 } & Eucalyptus urophylla (472) & Eucalyptus urograndis (132) \\
\hline & Dry mass of aerial part (g) \\
\hline 0,0 & $59.64 \mathrm{Aa}$ & $61.12 \mathrm{Aa}$ \\
200 & $52.92 \mathrm{ABa}$ & $58.05 \mathrm{ABa}$ \\
400 & $50.08 \mathrm{ABa}$ & $49.80 \mathrm{ABa}$ \\
600 & $36.70 \mathrm{Ba}$ & $47.27 \mathrm{Ba}$ \\
\hline & Dry mass of roots $\mathbf{( g )}$ & $19.40 \mathrm{Aa}$ \\
200 & $15.12 \mathrm{Ab}$ & $17.91 \mathrm{Aa}$ \\
400 & $16.63 \mathrm{Ab}$ & $15.65 \mathrm{ABa}$ \\
600 & $10.39 \mathrm{ABb}$ & $13.17 \mathrm{Ba}$
\end{tabular}

Médias seguidas de letras maiúsculas diferentes na coluna e minúsculas na linha, diferem entre si pelo teste de Tukey a 5 \% de probabilidade.

In clayey soil, the dry mass of the aerial portion of the two clones was similar in all sulfentrazone treatments while the root dry mass presented an interaction between the factors, where in the treatment with $200 \mathrm{~g} \mathrm{ha}^{-1}$, the E. urograndis was heavier than E. urophylla (Table 4). Carbonari et al. (2012) observed that the eucalyptus clone that absorbed higher quantities of sulfentrazone showed greater reductions of dry mass, in addition to more intense visual symptoms. 
Table 4. Dry mass of aerial part and roots of eucalyptus plants submitted to application of different sulfentrazone doses in clayey soil.

Tabela 4. Massa seca da parte aérea e raízes de plantas de eucalipto submetidas à aplicação de diferentes doses sulfentrazone em solo argiloso.

\begin{tabular}{ccc}
\hline \multirow{2}{*}{ Doses of sulfentrazone (g ha $\left.^{-1}\right)$} & \multicolumn{2}{c}{ Clone } \\
\cline { 2 - 3 } & Eucalyptus urophylla (472) & Eucalyptus urograndis (132) \\
\hline & Dry mass of aerial part (g) \\
\hline 0,0 & $32.15 \mathrm{Aa}$ & $39.56 \mathrm{Aa}$ \\
200 & $20.46 \mathrm{Aa}$ & $46.55 \mathrm{Aa}$ \\
400 & $48.32 \mathrm{Aa}$ & $38.07 \mathrm{Aa}$ \\
600 & $36.69 \mathrm{Aa}$ & $51.33 \mathrm{Aa}$ \\
\hline & Dry mass of roots (g) \\
\hline 00 & $11.95 \mathrm{Aa}$ & $13.53 \mathrm{Aa}$ \\
400 & $7.17 \mathrm{Ab}$ & $14.59 \mathrm{Aa}$ \\
600 & $14.30 \mathrm{Aa}$ & $9.95 \mathrm{Aa}$ \\
\end{tabular}

Médias seguidas de letras maiúsculas diferentes na coluna e minúsculas na linha, diferem entre si pelo teste de Tukey a 5 \% de probabilidade.

Figure 4 displays the results of concentrations of total chlorophyll for E. urophylla and of E. urograndis in sandy soil. At 15 DAA both clones showed significant reductions in the concentrations of the chlorophylls at the doses of 400 and $600 \mathrm{~g} \mathrm{ha}^{-1}$, whereas at 45 DAA negative effects were observed only at the higher dose and at 90 DAA; again the two highest doses. In clayey soil, E. urophylla did not display significant differences at 15 or 45 DAA, but in the final evaluation (90 DAA) higher concentrations of chlorophyll were found at the lowest sulfentrazone dose (Figure 5). In E. urograndis at 15 DAA all the sulfentrazone doses promoted reductions in the levels of chlorophylls in relation to the control. At 45 and 90 DAA no differences were observed between the treatments (Figure 5). Reductions in pigment concentrations due to the action of PROTOX inhibitors have been reported by diverse authors (Sherman et al., 1991; Monstowska et al., 1996; Tripathy et al., 2007; Carretero, 2008), as a consequence of oxidative stress, leading to a diminished photosynthetic efficiency.

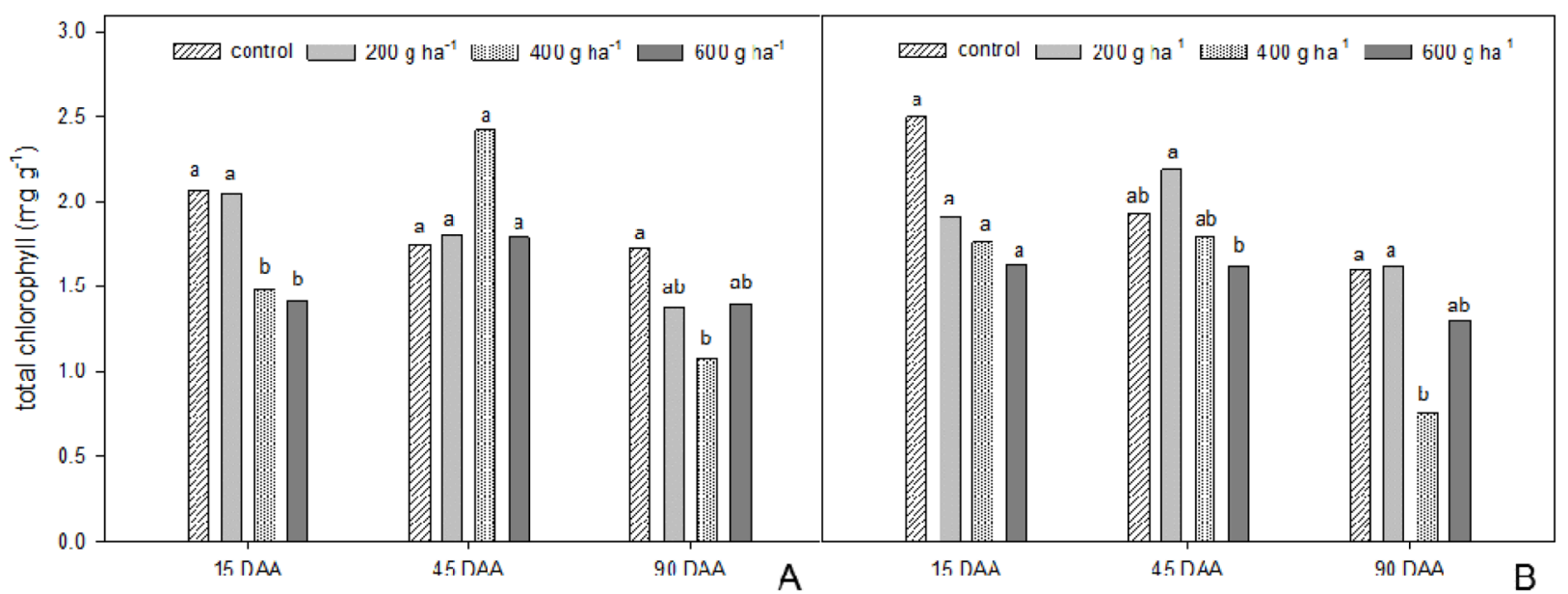

Figure 4. Concentration ( $\mathrm{mg} \mathrm{g}^{-1}$ ) of total chlorophyll $(\mathrm{Chl} \mathrm{a}+\mathrm{Chl} \mathrm{b})$ in plants of Eucalyptus urophylla (A) and Eucalyptus urograndis (B) in sandy soil after application of different sulfentrazone doses. Means followed by the same letter in each evaluation period do not differ from each other by Tukey's test at $5 \%$ probability.

Figura 4. Concentração $\left(\mathrm{mg} \mathrm{g}^{-1}\right)$ de clorofila total ( $\mathrm{Chl} \mathrm{a}+\mathrm{Chl} \mathrm{b)} \mathrm{em} \mathrm{plantas} \mathrm{de} \mathrm{Eucalyptus} \mathrm{urophylla} \mathrm{(A)} \mathrm{e} \mathrm{Eu-}$ calyptus urograndis (B) em solo arenoso após a aplicação de diferentes doses de sulfentrazone. Médias seguidas das mesmas letras dentro de cada período de avaliação não diferem entre si pelo teste de Tukey a $5 \%$ de probabilidade.

Figure 6 displays the results on availability of the sulfentrazone applied at different doses, in sandy and clayey soils. It was observed in both soils that the herbicide availability in the soil was directly proportional to the dose applied in the three periods of soil collection from pots. At 15 DAA the greatest availabilities of sulfentrazone in the soil were observed, with the concentrations differing highly between the clayey and sandy soils. At the higher dose, in clayey soil the maximum sulfentrazone availability observed was $47 \mu \mathrm{g} / \mathrm{kg}$ of soil, versus $185 \mu \mathrm{g} / \mathrm{kg}$ in the sandy soil solution. 


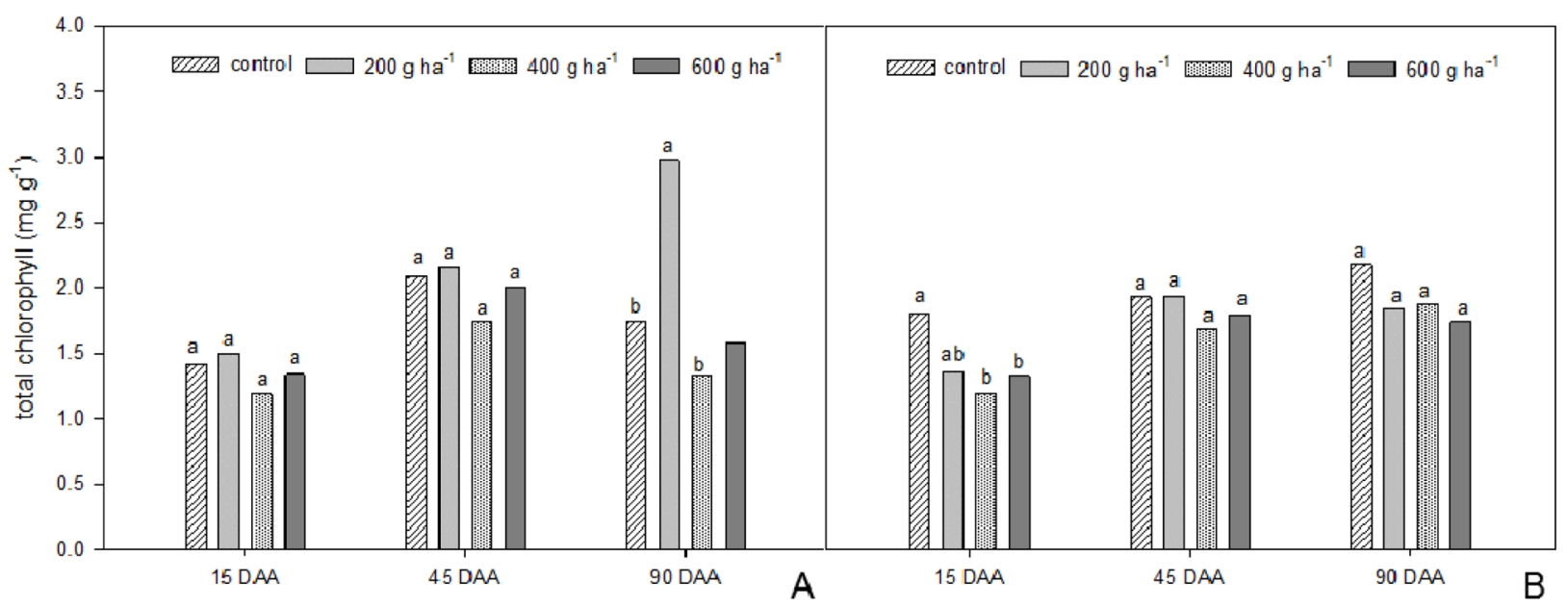

Figure 5. Concentration ( $\mathrm{mg} \mathrm{g}^{-1}$ ) of total chlorophyll $(\mathrm{Chl} \mathrm{a}+\mathrm{Chl} \mathrm{b})$ in plants of Eucalyptus urophylla $(\mathrm{A})$ and Eucalyptus urograndis (B) in clayey soil after application of different sulfentrazone doses. Means followed by the same letter in each evaluation period do not differ from each other by Tukey's test at $5 \%$ probability.

Figura 5. Concentração $\left(\mathrm{mg} \mathrm{g}^{-1}\right)$ de clorofila total $(\mathrm{Chl} \mathrm{a}+\mathrm{Chl} b)$ em plantas de Eucalyptus urophylla (A) e Eucalyptus urograndis (B) em solo argiloso após a aplicação de diferentes doses de sulfentrazone. Médias seguidas das mesmas letras dentro de cada período de avaliação não diferem entre si pelo teste de Tukey a $5 \%$ de probabilidade.
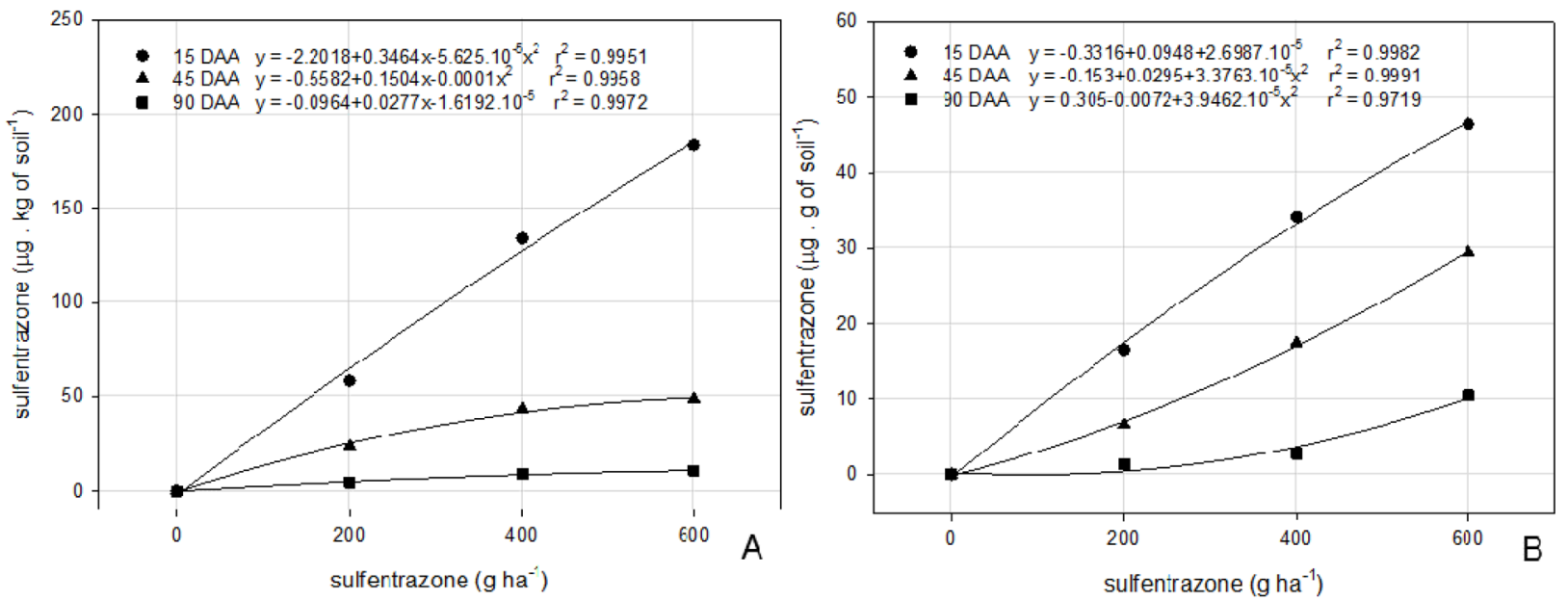

Figure 6. Availability of sulfentrazone in sandy (A) and clayey (B) soils at different applied doses.

Figura 6. Disponibilidade do sulfentrazone no solo arenoso $(A)$ e argiloso $(B)$ em diferentes doses aplicadas.

This finding demonstrates a greater sulfentrazone sorption in clayey soil, which represents availability almost four times higher of this herbicide in sandy soil in relation to clayey soil. The sorption and desorption of herbicides in soil regulate the phenomenon of retention, influencing transport, transformation and bioavailability of these molecules in the soil. These processes are directly related to the efficacy of herbicides in weed control, to the crop selectivity and to the risk of environmental contamination by these compounds.

In a soil solution, the herbicide tends to reach equilibrium between the portion in the sorbed phase and that which remains in solution. Absorption by the plants, the efficacy and the transport depend in large part on this equilibrium between the processes of sorption and desorption. Generally, the efficiency and mobility of the herbicides decreases along with the increase of its sorption by colloids in the soil (Oliveira et al., 2005).

According to Firmino et al. (2008), the sorption of herbicides on the surface of organic colloids and minerals of the soil accounts for part of the behavior presented by these molecules, among the diverse soil classifications, hampering the prediction of the behavior of these pesticides without prior knowledge of the factors that act on them. Given the wide variability in the physical, chemical and biological characteristics among soils, it is expected that the nature and intensity of sorption processes be also distinct. Thus, it is of fundamental importance to ascertain the physical-chemical characteristics of the soil so that one can estimate the behavior of the herbicide in the environment, 
which would enable its correct use, minimize the environmental impacts and augment the efficiency in its utilization (Firmino et al., 2008).

The higher levels de sulfentrazone found in sandy soil account for the greater intoxication levels observed in the two clones in this soil, although this difference is much smaller than that in the herbicide levels available. Both soils presented a highly significant drop in sulfentrazone levels during different periods evaluated, which is attributable to the degradation, absorption and lixiviation of the herbicide in the pots. At 45 DAA a greater reduction in availability of the herbicide in sandy than in clayey soil occurred, which can be explained by greater lixiviation of this herbicide in sandy soil, related to the lower sorption of this herbicide in the latter soil. At 90 DAA, highly similar levels were observed in both soils. Nevertheless, despite the reduced herbicide availability in the soil at 90 DAA, the intoxication symptoms in the eucalyptus plants persisted and were intense at 62 and 83 DAA as discussed previously.

\section{CONCLUSIONS}

It was observed that the two eucalyptus clones presented higher intoxication levels in sandy soil whereas the clone of $E$. urophylla showed higher sensitivity in relation to application of the herbicide sulfentrazone. The higher sulfentrazone dose in the two soils promoted reductions in the levels of chlorophyll. The intoxication levels observed in the two clones were proportional to the sulfentrazone dose in both soils while the availability of sulfentrazone was much higher in sandy than in clayey soil in the initial periods after application, but tended to be similar at the end of the period evaluated.

\section{REFERENCES}

ABRAF. Anuário estatístico da ABRAF 2013: Ano base 2012. Brasília, 2013.148 p.

CARBONARI, C. A. Efeito da palha na disponibilidade do herbicida amicarbazone na solução do solo em áreas cultivadas com cana-de-açúcar. 2009, 101 p. Tese (Doutorado em Agronomia de Proteção de Plantas) - Universidade Estadual Paulista, Botucatu, 2009.

CARBONARI, C. A.; VELINI, E. D.; GOMES, G. L. G. C.; TAKAHASHI, E. N.; ARALDI, R. Seletividade e absorção radicular do sulfentrazone em clones de eucalipto. Planta Daninha, Viçosa, v. 30, n. 1, p. 147-153, 2012.

CARBONARI, C. A.; VELINI, E. D.; SILVA, J. R. M.; BENTIVENHA, S. R. P.; TAKAHASHI, E. N. Eficácia da utilização de grânulos de argila como veículo para a aplicação aérea de sulfentrazone e isoxaflutole em área de implantação de eucalipto. Planta Daninha, Viçosa, v. 28, n. 1, p. 207-212, 2010.

CARRETERO, D. M. Efeitos da inibição da protoporfirinogênio IX oxidase sobre as trocas gasosas e fluorescência da clorofila a em plantas de soja (Glycine Max L. Merrill). 2008, 101 p. Dissertação (Mestrado em Fisiologia Vegetal) - Universidade Federal de Viçosa, Viçosa, 2008.

DAYAN, F. E.; WEETE, J. D.; DUKE, S. O.; HANCOCK, H. G. Soybean (Glycine max) cultivar differences in response to sulfentrazone. Weed Science, Champaign, v. 45, n. 5, p. 634-641, 1997.

DAYAN, F. E.; WEETE, J. D.; HANCOCK, H. G. Physiological basis for differential sensitivity to sulfentrazone by sicklepod (Senna obtusifolia) and coffee senna (Cassia occidentalis). Weed Science, Champaign, v. 44, n. 1, p. $12-17,1996$.

DUKE, S. O.; LYDON, J.; BECERRIL, J. M.; SHERMAN, T. D.; LEHNEN JR., L. P.; MATSUMOTO, H. Protoporphyrinogen oxidase inhibiting herbicides. Weed Science, Champaign, v. 39, n. 3, p. 465-473, 1991.

FIRMINO, L. E.; TUFFI SANTOS, L. D.; FERREIRA, F. A.; FERREIRA, L. R.; TIBURCIO, R. A. S. Sorção do imazapyr em solos com diferentes texturas. Planta Daninha, Viçosa, v. 26, n. 2, p. 395-402, 2008. 
Carbonari et al. - Differential tolerance of eucalyptus clones to sulfentrazone applied in different soil textures

FMC. Manual de produtos. Campinas, 1997. 77 p.

LICHTENTHALER, H. K. Chlorophylls and carotenoids: pigments of photosintetic biomembranes. Methods in Enzymology, v. 148, p. 350-382, 1987.

MACHADO, A. F. L.; FERREIRA, L. R.; SANTOS, L. D. T.; FERREIRA, F. A.; VIANA, R. G.; MACHADO, M. S.; FREITAS, F. C. L. Eficiência fotossintética e uso da água em plantas de eucalipto pulverizadas com glyphosate. Planta Daninha, Viçosa, v. 28, n. 2, p. 319-327. 2010.

MOSTOWSKA, A.; SIEDLECKA, M.; PARYS, E. Effect of 2,22-bipyridyl, a photodynamic herbicide, on chloroplast ultrastructure, pigment content and photosynthesis rate in pea seedlings. Acta Physiology Plantarum, v. 18, p. 153-164, 1996.

OLIVEIRA M. F.; PRATES, H. T.; SANS, L. M. A. Sorção e hidrólise do herbicida flazasulfuron. Planta Daninha, v. 23, n. 1, p. 101-113, 2005.

OLIVETTE, M. P. A.; CASTANHO FILHO, E. P.; SACHS, R. C. C.; NACHILUK, K.; MARTINS, R.; CAMARGO, F. P.; ÂNGELO, J. A.; OLIVEIRA, L. H. D. C. L. Evolução e prospecção da agricultura paulista: liberação da área de pastagem para o cultivo da cana-de-açúcar, eucalipto, seringueira e reflexos na pecuária, 1996-2030. Informações Econômicas, São Paulo, v. 41, n. 3, p. 37-67, 2011.

RODRIGUES, B. N.; ALMEIDA, F. S. Guia de herbicidas. 6.ed. Londrina: Edição dos Autores, 2011.697 p.

SBCPD - SOCIEDADE BRASILEIRA DA CIÊNCIA DAS PLANTAS DANINHAS. Procedimentos para instalação, avaliação e análise de experimentos com herbicidas. Londrina, 1995. 42 p.

SCALLA, R.; MATRINGE, M.; CAMADRO, J. M.; LABBE, P. Recent advances in the mode of action of diphenyl ether and related herbicides. Zeitschrift für Naturforschung, v. 45, n. 5, p. 503-511, 1990.

SHERMAN, T. D.; BECERRIL, J. M.; MATSUMOTO, H.; DUKE, M. V.; JACOBS, J. M.; JACOBS, N. J.; DUKE, S. O. Physiological basis for differential sensitivities of plant species to protoporphyrinogen oxidase-inhibiting herbicides. Plant Physiology, Bethesda, v. 97, n. 1, p. 280-287, 1991.

TOlEDO, R. E. B.; VICTORIA FILHO, R.; ALVES, P. L. C. A.; PITELLI, R. A.; LOPES, M. A. F. Faixas de controle de plantas daninhas e seus reflexos no crescimento de plantas de eucalipto. Scientia Florestalis, Piracicaba, n. 64, p. $78-92,2003$.

TRIPATHY, B. C.; MOHAPATRA, A.; GUPTA. I. Impairment of the photosynthetic apparatus by oxidase stress induced by photosensitization reaction of protoporphyrin IX. Biochimica et Biophysica Acta, v. 1767, n. 6, p. $860-868,2007$

TUFFI SANTOS, L. D.; FERREIRA, L. R.; FERREIRA, F. A.; DUARTE, W. M.; TIBURCIO, R. A. S.; MACHADO, A. F. L. Intoxicação de Eucalipto Submetido à Deriva Simulada de Diferentes Herbicidas. Planta Daninha, Viçosa, v. 24, n. 3, p. 521-526, 2006.

TUFFI SANTOS, L. D.; MACHADO, A. F. L.; VIANA, R. G.; FERREIRA, L. R.; FERREIRA, F. A.; SOUZA, G. V. R. Crescimento do eucalipto sob efeito da deriva de glyphosate. Planta Daninha, Viçosa, v. 25, n. 1, p. 133-137, 2007.

VAUGHN, K. C.; DUKE, S. O. Mechanisms of resistance. In: EBING, W. (Ed.) Chemistry of Plant Protection. New York: Springer-Verlag, 1991, p. 142-169.

Recebido em 08/05/2014

Aceito para publicação em 30/07/2015 